97）越智, 小林：信学論誌, J70-B, 1, pp. 66-76（1987）

98）嶋田，伊東，宇都宮：信学技報, CS 86-141（1987）

99）中村, 如沢, 富永：信学技報, IE 86-111（1987）

100）三王, 中村, 南：信学技報, IE 87-71 (1987)

101）山根, 森川, 浜田：信学論誌, J69-B, pp. 686-697 (1986)

102）大関, 上谷：PCSJ 87, 4-11 (1987)

103) 吉田, 河内：PCSJ 87, 4-12（1987)

104) 坪井, 岡本: PCSJ 87, 4-13 (1987)

105）加藤, 武川, 大久保：信学論誌, J71-B, 1, pp. 1-9 (1988)

106) 石橋, 小倉：信学論誌, J69-B, 6, pp. 598-608 (1986)

107) 遠藤, 山崎：信学論誌, J70-B. 1, pp. 105-114 (1987)

108）金, 加藤, 安田：PCSJ 87，1-3 (1987)

109）真下, 恩田, 小沢：信学論誌, J71-B, 2, pp. 164-171（1988）

110）井沢，木村, 滝沢 : PCSJ 87, 4-1 (1987)

111）中嶋, 鄭, 安居院：信学技報, IE 87-76 (1987)

112）木原, 伊東, 宇都宮：信学技報, IE 87-100（1987）

113）点,下野, 北島, 小川：信学論誌, J71-A, 2, pp. 481-487 (1988)

114）町澤, 吉田：PCSJ 86, 3-3 (1986)

115）佐藤, 大石：信学技報, IE 86-93 (1987)

116）宮原，八島，青野：信学技報, IE 87-51（1987）

117）篠原, 南：PCSJ 87, 7-6 (1987)

118）宮原, 堀田：信学技報, IE 87-115（1988）

119）滝沢，吹抜：PCSJ 86，6-2（1986）

120）浜, 高原：信学技報, IE $86-89$ (1986)

121）海野, 高橋, 田坂：信学論誌, J70-B, 8, pp. 958-966 (1987)

122) 佐藤, 高橋, 太田：信学論誌, J69-B, 8, pp. 809-815 (1986)

123）谷口, 上倉, 伊東, 宇都宮：信学論誌, J70-B, 6, pp. 654-663 (1987)

124）大久保：テレビ誌, 40，3，pp. 178-183 (1986)

125）山本：テレビ誌, 40, 12, pp. 1211-1217 (1986)

126）橋本：信学技報, IE 87-68（1987）

127）太田, 古閑：信学技報, IE 86-112（1987）

128）小池，金子，羽鳥：信学技報，IE 87-52（1987）

129）渡邊, 駄竹, 杉山：信学技報, IE 87-70（1987）

130）滝沢，井沢，木村，吹抜：信学技報，IE 87-97（1987）

131）松田, 小杉, 酒井, 堀田, 津田：信学論誌, J71-A, 2, pp. 488-
$496(1988)$

132）伊藤, 村上：PCSJ 86，6-3（1986)

133）渡辺，星野，黒田，橋本：信学技報, IE $87-120$ (1988)

134）浅井, 上澤, 村上：PCSJ 87，3-1（1987）

135）鈴木, 長谷, 橋本：信学技報, IE 86-14（1986）

136）鈴木：信学技報, IE 87-98（1987）

137) 斉藤, 松本：PCSJ 87，7-9（1987）

138）上倉, 沢田：昭 62 信学情報・システム全大, 202 (1987)

139）二宮，川島：信学技報, IE 86-69（1986）

140) 谷本, 千葉, 影山：信学論誌, J70-B, 10, pp. 1132-1139 (1987)

141）谷本，森：信学技報, CS 86-1 (1986)

142）岸本, 桜井：信学技報, IE 86-73 (1986)

143）伊藤, 牧, 川井, 岡崎, 松田, 津田：信学技報, IE 86-75（1986）

144）八島, 沢田：信学論誌, J70-B, 1, pp. 96-104 (1987)

145）野垣，太田，古閑：PCSJ 87，8-1（1987）

146) 安田：PCSJ 87, 5-6 (1987)

147）緒方, 岸本, 犬丸：信学技報, IE 87-83（1987）

148）野村, 藤井, 太田：信学論誌, J71-A, 2, pp. 426-433（1988）

149）加藤, 安田：PCSJ 87，8-6（1987）
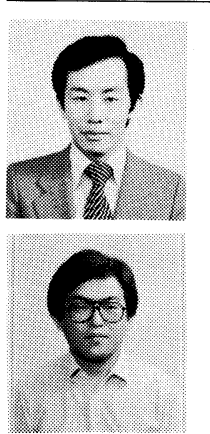

斎藤 隆弘 昭和 56 年, 東京大学大学院 電気工学専攻博士課程修了。同年, 神奈川大 学工学部専任講師. 58 年, 同助教授となり, 現在に至る. 画像通信, 画像処理, 信号処 理, 医用応用などの研究に従事. 工学博士. 正会員.

\title{
6-2 画像処理と画像理解
}

\section{1. まえがき}

画像診断は日常のこととなり, 狭い帯域幅で HDTVが送られるようになる日も近い。 それらの基 礎は画像処理技術である. 日本の画像研究者の社交場 の意味を持つ画像工学コンファレンスは, 昭和 45 年 第 1 回開催以来, 年を追って発展しているが, 現在の 演題は応用を志向した画像処理が主流である。これと

$\dagger$ 電子技術総合研究所 画像処理研究室

†† 電気通信大学 電子工学科

"6-2 Image Processing and Image Understanding" by Katsuhiko Sakaue (Image Processing Section, Electrotechnical Laboratory, Ibaraki) and Shin Hasegawa (Department of Electronic Engineering, The University of Electro-Communications, Tokyo)
坂 上 勝 彦 $^{\dagger}$, 正会員 長谷川 伸 $^{\dagger \dagger}$

同じ期間に開催される国際画像機器展も画像処理機器 展の感が強く, 参加者は 3 日間で 12,000 名を超え, 関係技術者の数の多いことを思わせる。

以下, 画像処理の手法別に研究開発の動向を述べ る.

\section{2. ハードウェアによるアナログ画像処理}

ディジタル画像処理技術の進展により，アナログ的 な処理の研究発表は極めて少なくなった。しかし，デ イジタル処理に比べ低コスト, 高速に処理できる利点 があり，コヒーレント光画像処理を併用した高速の縞 解析システム ${ }^{1)}$, 血管造影用 $\mathrm{X}$ 線テレビのリアルタイ 厶画像減算処理 ${ }^{2)}$, 液晶カラーテレビの受像機を利用 
したカラーパターン認識3などが試みられている。

\section{3. 光学画像処理}

光学画像処理の研究は国内では下火である. 外国で は論文が多く, 光学関係誌には分野別の特集号も多い が，実用面ではいま一歩の感がある。

Opt. Eng. 誌 25 巻 7 号（1986）は, 宇宙ステーショ ン応用の特集で, NASA で行われている宇宙ステー ション自動化のための光学画像処理 ・ 認識のレビュ ${ }^{4)}$, 波長可変ダイレーザを用い大きさや方向の異な るパターンに適用できる画像認識5), Foley-Samon 変換による画像分類 ${ }^{6}$ ほか 9 編の論文がある.JOSA 誌 A3 巻 7 号, 8 号（共に 1986）は, 光の干渉性と統 計的性質の応用の特集号であり, レーザ光源のスペッ クルが重畳するパターンの光学的認識7), 金属面の粗 面度の計測 ${ }^{8)}$ その他, 多くの論文がある.

光学的変換については, ピンホール行列からなるサ ンプリングフィルタを用いたレンズなしフーリエ変換 光学系 ${ }^{9}$ のほか, ヒルベルト変換 ${ }^{10)}$ やフ変換 ${ }^{11}$ を行 う光学系が研究されている.また，フィルタリング ${ }^{22}$ や部分的にコヒーレントな光を用いる光学的認識の手

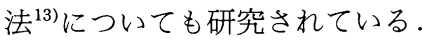

光学系による前処理と簡単なディジタル処理を組合 せたものでは,メディアンフィルタリングを実行する システム ${ }^{14)}$, 波長スペクトルと空間スペクトルフィル 夕と計測器を組合せたカラー画像認識システム ${ }^{15)}$ ど, 多くの研究が行われている.

光学画像処理に関連した分野に光コンピュータがあ り，2つの方向の研究論文が米国で大量に発表されて いる。ひとつは，パターン化した情報に対し論理演 算, 行列演算などを並列高速処理するもので, Appl. Opt. 誌 25 巻 10 号, 18 号（共に 1986）, Opt. Eng. 誌 26 巻 1 号 (1987) の光コンピュータ特集号にこの分野 の論文が多い. 他のひとつは, 光演算を行う場合の論 理ゲート, 光双安定等の素子や, これらの間の信号授 受のための光インタコネクションであり，本号 9-2 節 の光デバイスをご参考頂くこととし, ここでは特集号 のみあげて扔く ${ }^{16) \sim 18)}$.

このような光コンピュータの応用としてレーザ, 音 響光学素子による回折, フィルタリング, 光検出器を 組合せ，CT 像をリアルタイムに再構成表示するシス テムが提案されている ${ }^{199}$. 光コンピュータについては 我が国でも注目を集め始めているが，期待を寄せる意 見と同時に悲観的な見方もある。

\section{4. ディジタル画像処理}

ディジタル画像処理の研究, 開発, 実用化は, あい かわらず活発に行われている。昭和 61 年 3 月までの 動向については, SPIDER 第 2 期版の開発に伴って 執筆された解説シリーズ $\left(1\right.$ 冊の本 ${ }^{20}$ にまとめられて いる）が役に立つ。これと前回のテレビジョン年報と を合わせれば，昭和 60 年度まではほぼ完壁に網羅さ れているといえる。 それ以降, 最近 2 年間の大きな動 向としては, 画像認識・理解の枠組みとして知識利用 が再び活発化してきたこと，興味深い画像処理専用八 ードウェアの開発・実用化が進みつつあること，があ げられる。これらについては 5 節， 6 節でとりあげ る。本節ではそれ以外に注目すべき最近のディジタル 画像処理手法について技術動向を概観する.

局所処理によるエッジ検出では，現在 Canny の Operator ${ }^{211}$ がアメリカを中心に評判となっている. 基本的にはガウシアン 1 次微分コンボリューションと Non-Maximum Suppression の組合せである。これ を含めた解説・比較 ${ }^{22)}$, 改良版の提案など, 盛んな議 論が行われている，ただし，インプリメントの方法は 論文からでは読み取りにくい，米国では Lispで書か れたプログラムが広まっているようである。また，従 来から使われていたゼロクロッシングオペレータの改 良も盛んである ${ }^{23) ~ 25) . ~}$

コンピュータグラフィックスの分野で使われていた フラクタルを, 画像解析, 特にテキスチャ解析に応用 しようという提案がある ${ }^{26)}$. 自然現象によるパターン の記述に有効であろう. 地形の記述 ${ }^{27)}$, リモートセン シング画像での雲と雪の分類 28$)$ 等, 具体的な応用が進 んでいる.

2 值化のための閾值決定法では, Kittler らの方 法吕が注目されている。これは 2 群の分布の割合が極 端に片寄っている場合にも良好な分類結果を与える手 法である. 大津 ${ }^{30}$ によって情報理論的な意味付けがな されている．この手法を含めた比較実験の報告もあ $る^{31)}$.

波形あるいは形状の解析手法としては, Witkinに よって Scale-Space Filtering が提案されている ${ }^{32}$. 理論の展開, 2 次元形状等への応用が試みられてい る ${ }^{33) ~ 38)}$.また, Witkin等は, SNAKES という柔軟 な輪郭マッチングアルゴリズムも提案している ${ }^{39)}$.こ れは主観的輪郭の検出にも応用できるようである．

ステレオビジョンによる 3 次元情報抽出では, 多眼 ステレオがひとつの研究動向となっている．3眼ステ レオ ${ }^{40) 41)}$, 連続的な多眼ステレオ ${ }^{42)}$, 等が興味深い. 
3 次元画像処理を含む総合システムの例としては自動 走行ロボット (ALV: Autonomous Land Vehicle) が有名である ${ }^{43)}$. 一方, 単眼で 3 次元情報を抽出する 手法, すなわち 2 次元画像配列から, 見えている 3 次 元表面の物理的性質を発見するプロセスは early vision と呼ばれている. early vision を変分法を使っ た一般的な枠組みで解こうという regularization theory が提唱されている ${ }^{44) ~ 46)}$. 文献 47) は立体認識手法 の分かりやすい解説である.

色情報に関する手法としては, ハイライトの処理手 法 ${ }^{48)}$, 色とレンジファインダを組合せた 3 次元計測手 法 ${ }^{49)}$ 等がある。

\section{5. 画像認識，画像理解}

知識工学の手法や成果を利用した画像処理や画像理 解システムの研究が, この分野の最新の研究動向であ る. 従来は米国を中心に対象の構造に関する知識に関 わるものが主流であった ${ }^{50)}$. しかしここ $2 ， 3$ 年の新 しい試みとして，画像処理技術に関する知識を扱う画 像処理エキスパートシステムの研究が特に我が国にお いて活発化し, 注目されている(1152).

対象に関する知識については, 医学の専門的な知識 を導入したシステム ${ }^{53154)}$, 3 次元モデルの利用 ${ }^{55)}$, 空 間的関係に関する知識の利用 ${ }^{56)}$ ，ボトムアップとトッ プダウン解析の統合 ${ }^{57)}$ 等の試みがある。また興味深い 誌上討論 ${ }^{58)}$, 解説 ${ }^{59)}$ もる.

画像処理エキスパートシステムの研究は, 画像処理 のためのコンサルテーションシステムで始まったとい える. DIA-Expert システムの構想 ${ }^{511}$ 以来, いくつか のシステムが実際に開発されている ${ }^{60) ~ 71)}$. ゴールと して与えられた画像特徵を検出するための画像処理ア ルゴリズムを自動的に選択あるいは生成し実行する画 像処理エキスパートシステムも提案されている ${ }^{72) ~ 76) . ~}$ 多くの解説もある ${ }^{52777) ~ 81) . ~}$

コンピュータビジョンにおける学習の問題は常に重 要な課題として研究されている. 記号処理と信号処理 とを統合したシステムにおいて学習を議論した論文が いくつか見られる ${ }^{82)-89)}$. 人間の視覚に学ぶアプロー チもハードウェアの進歩によって現実性を持ち始めて いる ${ }^{90)}$. 特にPDP (Parallel Distributed Processing) ${ }^{91)}$ と呼ばれる考え方の提案以来, 理論, 実験, ハードウ エア等の議論が高まっている.

\section{6. 画像処理ハードウェア}

ディジタル画像処理を高速に行う画像処理専用ハー ドウェアは, LSI・VLSI 技術の急速な進歩により，商
品化も進み, 画像処理システムの核として広く使われ 始めている. 最近になっても興味深いアーキテクチャ の装置が提案・開発されている. 完全並列型の AAP $2^{92)}$ は, パソコンワークステーション用の外付けアク セラレータとして利用できる。ロボットの視覚のため のマルチプロセッサの試みとしては, マルチウィンド ウ $\mathrm{LSI}^{93)}$ を使用したシステムが面白い。局所並列型ア 一キテクチャの改良開発は多く, コンパクト化・低価 格化が進んである. 最近は, Sun 3 等の Unix マシン のバスに直結し，ホストの主記憶と画像メモリーとを シェアできるタイプのものが急速に增えている，パイ プラインを使ったものとしては, 画像処理用 LSIISP-II ${ }^{94)}$ や シストリックアレイによる Warp ${ }^{43)}$ があ る. 可変パイプラインによる柔軟なアーキテクチャの 具体例としては, ImPP ${ }^{95)}$ と韋駄天 ${ }^{96)}$ がある. DSTP9506 ${ }^{97)}$ は画像処理向きのコプロセッサである. 人工知能向きアーキテクチャについては文献 98)に解 説がある。

\section{7. むす び}

最近の画像処理と画像理解の研究動向について述べ た. 文中, ハードウェアによるアナログ画像処理, 光 学画像処理を長谷川, その他を坂上が担当した.この 分野の研究は活発で膨大な数の論文を網羅することは 到底不可能であった，分類誤り，選出の扁り等は扔許 し頂きたい.

(昭和 63 年 4 月 13 日受付)

\section{〔参 考 文 献〕}

1) 豊岡, 大橋: 光学, 16, 9, pp. 407-413 (Sep., 1987)

2) A. Suwa, et al. : Proc. Jpn. Disp., 14-8 (Oct., 1986)

3) F. T.S. Yu, et al.: Opt. Eng., 26, 5, pp. 453-460 (May, 1987)

4) D. J. Ennis and D. A. Jared : Opt. Eng., 25, 7, pp. 808-820 (July, 1986)

5) T. H. Chas and M. Chen : ibid, pp. 828-833 (July, 1986)

6) O. Tian, et al.: ibid, pp. 834-840 (July, 1986)

7) J. Marron and G. M. Morris: JOSA, A-3, 7, pp. 964-971 (July, 1986)

8) J. Ohtsubo: ibid, pp. 982-987 (July, 1986)

9) A. Kofodziejczyk: Optz Acta, 32, 6, pp. 741-746 (1985)

10) Y. L. G. Eichmann: OpT, Comm., 58, 6, pp. 379-384 (July, 1986)

11) W. H. Steier and R. K. Shori : Appl. Opt., 25, 16, pp. 2734-2738 (Aug., 1986)

12) B. Kuhlow: Appl. Opt., 25, 14, pp. 2351-2356 (July, 1986)

13) B. Javidi : ibid, pp. 2365-2371 (July, 1986)

14) E. Ochoa, et al. : Appl. Opt., 26, 2, pp. 252-260 (Jan., 1987)

15) Z. H. Gu: Appl. Opt., 26, 15, pp. 3145-3152 (Aug., 1987)

16) Optical Information Processing 特集, Opt. Eng., 25, 2 (Feb., 1987)

17) Optical Computing 特集, Appl. Opt., 25, 14 (July, 1986)

18) Optical Interconnection 特集, Appl. Opt., 25, 10 (May, 1986)

19) A. F. Gmitro, et al. : Appl. Opt., 24, 22, pp. 4040-4045 (Nov., 1985)

20）高木, 鳥脇, 田村編：“画像処理アルゴリズムの最新動向”, 別冊 $\mathrm{O}$ plus $\mathrm{E}$, 新技術コミュニケーションズ (1986)

21) J. Canny: IEEE Trans., PAMI-8, 6 , pp. 679-698 (1986) 
22) V.S. Nalwa and T. O. Binford: IEEE Trans., PAMI-8, 6, pp. 699-714 (1986)

23) R. M. Haralick : IEEE Trans., PAMI-6, 1, pp. 58-68 (1984)

24) W. H. H. J. Lunscher and M. P. Beddoes : IEEE Trans., PAMI-8, 2, pp. 164-177 (1986)

25) W. H. H. J. Lunscher and M. P. Beddoes: IEEE Trans., PAMI-8, 2, pp. $178-187$ (1986)

26) A. P. Pentland: IEEE Trans., PAMI-6, 6, pp. 661-674 (1984)

27）横矢，山本，舟久保：信学論誌，J70-D, 12, pp. 2605-2614（1987）

28）中山, 曽根, 高木: 情報処理学会研資, コンピュータビジョン 444 (1986)

29) J. Kittler and J. IIIingworth: Pattern Recognition, 19, 1, pp. 41 -47 (1986)

30) 大津：昭和 63 年信学春季全大, D-218（1988）

31) P. K. Sahoo, S. Soltani, A. K. C. Wong, and Y. C. Chen : Computer Vision, Graphics, and Image Processing, 41, pp. 233-260 (1988)

32) A. P. Witkin: Proc. 8th IJCAI, pp. 1019-1022 (1983)

33) H. Asada and M. Brady: IEEE Trans., PAMI-8, 1, pp. 2-14 (1986)

34) A. L. Yuille and T. A. Poggio: IEEE Trans., PAMI-8, 1, pp. 15 -25 (1986)

35) J. Babaud, A. P. Witkin, M. Baudin, and R. O. Duda : IEEE Trans., PAMI-8, 1, pp. 26-33 (1986)

36) F. Mokhtarian and A. Mackworth: IEEE Trans., PAMI-8, 1, pp. 34-43 (1986)

37) M. J. Carlotto: IEEE Trans., PAMI-9, 1, pp. 121-129 (1987)

38）酒匂, 大内, 井内, 依田：昭和 63 年信学春季全大, D-224（1988）

39) M. Kass, A. Witkin, and D. Terzopoulos: Proc. of 1st ICCV, pp. 259-268 (1987)

40）山本, 大田, 池田：情報処理学会研資, コンピュータビジョン 464 (1987)

41）北村，来海，谷内田：信学技報, PRU 86-2（1986

42）山本：情報処理学会研資, コンピュータビジョン 45-3（1986）

43) M. Hebert and T. Kanade: Proc. International Workshop on Industrial Application of Machine Vision and Machine Intelligence (SEIKEN Symposium), pp. 375-380 (1987)

44) T. Poggio, V. Torre, and C. Koch: Nature, 317, 26, pp. 314-319 (1985)

45) D. Terzopoulos: IEEE Trans., PAMI-8, 4, pp. 413-424 (1986)

46) V. Torre and T. Poggio: IEEE Trans., PAMI-8, 2, pp. 147-163 (1986)

47) 杉原：テレビ誌, 41, 9, pp. 787-793 (1987)

48) G. J. Klinker, S. A. Shafer, and T. Kanade: Proc. of 1st ICCV, pp. 145-150 (1987)

49）田島：情報処理学会研資, コンピュータビジョン 44-3 (1986)

50）大田，金出：情報処理, 24, 12, pp. 1446-1452（1983）

51）田村，坂上：信学技報, PRL 83-49（1983）

52) 田村：第 16 回画像工学コンファレンス予稿集, pp. 89-94（1985）

53) S. A. Stansfield : IEEE Trans., PAMI-8, 2, pp. 188-199 (1986)

54) H. Niemann, H. Bunke, I. Hofmann, G. Sagerer, F. Wolf, and H. Feistel : IEEE Trans., PAMI-7, 3, pp. 246-259 (1985)

55) R. A. Brooks, R. Greiner and T. O. Binford: Proc. of IJCAI, pp. 105-113 (1979)

56) D. M. McKeown, Jr., W. A. Harvey, and J. McDermott: IEEE Trans., PAMI-7, 5, pp. 570-585 (1985)

57）松山，ハング：情報処理学論誌, 26, 5, pp. 877-889 (1985)

58) A. Rosenfeld, et al. : Computer Vision, Graphics, and Image Processing, 34, pp. 99-117 (1986)

59) A. R. Rao and R. Jain: IEEE Expert, Spring 1988, pp. 64-79 (1988)

60）末田ほか：東芝レビュー，40，5，pp. 403-406（1985）

61）鳥生, 岩瀬, 後藤, 吉田: 情報処理学論誌, 29, 2, pp. 150-159 (1988)

62）折田, 金崎, 小沼, 高藤：信学技報, PRU 86-49（1986）

63）田村, 佐藤, 坂上, 久保: 情報処理学論誌, 29, 2, pp. 199-208
(1988)

64）坂上, 田村：情報処理学論誌, 26, 4, pp. 652-661（1985）

65）久保, 佐藤, 坂上, 田村：情報処理学論誌, 29, 2, pp. 209-219 (1988)

66）鈴木，本多，鳥脇：情報処理学論誌，29, 1, pp. 29-37（1988）

67）村上, 輿水, 長谷川：情報処理学論誌, 29, 2, pp. 114-125（1988）

68）稲田，松本：情報処理学論誌，29,2, pp. 142-149（1988）

69）谷口, 古賀, 河口: 情報処理学論誌, 29, 2, pp. 190-198（1988）

70) M. Goldberg, D. G. Goodenough, M. Alvo, and G. M. Karam: Proc. of the IEEE, 73, 6 (1985)

71）富田：情報処理学論誌，29,2, pp. 96-104（1988）

72）松山，尾崎：情報処理学論誌，27, 2, pp. 191-204（1986）

73）長谷川，久保田，鳥脇：信学技報, PRL 85-38（1985）

74）長谷川, 久保田, 高須, 鳥脇: 情報処理学論誌, 29, 2, pp. 126133 (1987)

75）棟安, 大宅：映像情報（I ），1987-1，pp. 53-60（1987）

76) A. M. Nazif and M. D. Levine: IEEE Trans., PAMI-6, 5, pp. 555 -577 (1984)

77）加藤，木戸出：テレビ誌， $41,10, p p .872-880$ (1987)

78）松山：映像情報（I ），1986-1，pp. 19-25（1986）

79）坂上：テレビ誌， 41,9 , pp. 801-807（1987）

80）田村：信学会技報, IE $86-8$ (1986)

81) 吉田: OHM, 10, pp. 33-37 (1986)

82）伊東, 高木ほか：信学論誌, J69-D, 7, pp. 1083-1094(1986)

83）安部, 西田, 辻：情報処理学論誌, 25, 5, pp. 755-763(1984)

84) P. H. Winston, T. O. Binford, et al. : AAAI-83, pp. 433-439 (1983)

85) J. H. Connell and M. Brady : IJCAI-85, pp. 922-925 (1985)

86) J. H. Connell and M. Brady : Artificial Intelligence, 31, 2, pp. 159 -183 (1987)

87) 山本, 坂上, 松原, 山岸: 情報処理学会第 35 回 (昭和 62 年度後期) 全大, 4 K-3 (1987)

88）松原, 山本, 坂上, 山岸：信学技報, PRU 88-19（1988）

89）坂上, 山本, 松原, 山岸：信学技報, PRU 88-20（1988）

90) 福島：テレビ誌, 41, 9, pp. 780-786 (1987)

91) D. E. Rumelhart, J. L. McClelland, and The PDP Research Group: "Parallel Distributed Processing: Explorations in the Microstructures of Cognition", A Bradford Book, MIT Press (1986)

92）近藤，多田，宮原：信学総合全大，1252（1987）

93) 井上ほか:第 3 回日本ロボット学会学術講演会予稿集, p. 163 (1985)

94）小林, 三浦, 福島, 金崎, 浅田, 児島：信学全大, 1243 (1987)

95）岩下, 天満：第 2 回産業における画像センシング技術シンポジウ 厶, pp. 5-10 (1987)

96) 佐々本, 佐藤, 岩瀬, 後藤: 情報処理学会コンピュータビジョン研 資，37-1（1985）

97）加沼ほか：日経エレクトロニクス，408，p.183（1987）

98) 雨宮：テレビ誌, 41,9 , pp. 794-800 (1987)

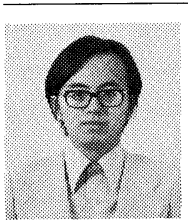

圾妿 勝彦 昭和 56 年, 東京大学大学院 電子工学専門課程修了. 同年, 電子技術総合 研究所に入所し, 現在に至る。パターン認 識, 画像処理などの研究に従事. 工学博士. 正会員.

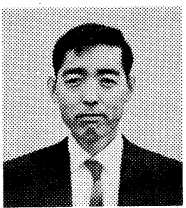

長谷川俥昭和 29 年, 東京大学工学部 応用物理学科卒業. 同年, (株) 東芝に入社. 42 年, 電気通信大学に移り, 現在, 同大学 電子工学科教授. 画質処理, 光電変換電子装 置の研究開発に従事. 工学博士. 正会員. 